\title{
Mitomycin B
}

National Cancer Institute

\section{Source}

National Cancer Institute. Mitomycin B. NCI Thesaurus. Code C1392.

A methylazirinopyrroloindoledione antineoplastic antibiotic isolated from the bacterium Streptomyces caespitosus. Bioreduced mitomycin B generates oxygen radicals, alkylates DNA, and produces interstrand DNA cross-links, thereby inhibiting DNA synthesis.

$(\mathrm{NCl04})$ 